\title{
直線位相スイッチトキャパシタフィルタの一実現法*
}

\author{
金台烋**.岩田彰**.浅葉 統太 $* *$. 大友 博**
}

\section{An Implementation of Switched-Capacitor Filters with Linear Phase*}

Taikyu KIM**, Akira IwATA**, Touta AsabA** and Hiroshi Онтомо**

\section{1.はじめに}

信号の処理・補間などにさいしては位相ひずみの無い （群遅延一定）直線位相フィルタが望まれ，周知のように， アナログおよびディジタルの両系にわたってさまざまな 工夫がなされている。そして低域通過型の帯域制限を受 けた時間連続信号の離散値系列から，もとの連続信号を 復元するためのラグランジュB -フィルタは正確な直線 位相特性を備えている1),2)。さらに, 低次系による速い 信号処理と高次系の急峻な遮断特性とを有する直線位相 フィルタ系を得るために Bーフィルタを並列合成した構 成手法が示されている1)。 また，サンプリング技術を応 用したアナログ回路であるスイッチトキャパシタ回路は 集積化に好都合であるから，信号処理・計測・制御・情報 伝送などのシステムに応用されていることはよく知られ ている.

ここでは集積化に便利な直線位相アナログフィル夕の 実回路による形成を意図し，スイッチトキャパシタ回路 を使用して B ーフィルタの並列合成手法に基づいた低域 通過フィルタを試作し, 応答例を示している。

\section{2. 直線位相フィルタの並列合成 ${ }^{1), 2)}$}

音声の場合などのように，低域通過型の帯域制限を受 けた連続時間信号が一定時間間隔の離散時間信号系列と して与えられているとき, この信号系列から，もとの連続 時間信号を復元するためのラグランジュBーフィルタ1),2) は, 零次サンプルホールド要素, 積分要素および線形加 算要素からなる系として構成できる，入力離散時間信号 系列の周期が $T$ のとき, $m$ 次 $\mathrm{B}$-フィルタのインパル 又応答 $b_{m}(t)$ は時間 $t=(m+1) T / 2$ における最大值の

* 原稿受付 1997 年 7 月 2 日

** 青山学院大学 理工学部 College of Science and Engineering, Aoyama Gakuin University; 6-16-1 Chitosedai, Setagaya-ku, Tokyo 157-0071, JAPAN

Key Words: discrete signal, reconstruction, linear phase filter, signal processing, interpolation.
両側で単調に推移し， $t \geqq(m+1) T$ では消滅する非負偶 関数対称波形である. $m$ 次 $\mathrm{B}$-フィル夕の周波数応答 $B_{m}(j f)$ ( $f$ : 周波数) の位相特性は $-(m+1) \pi f T$ であ り $f$ に関して直線である. また, 直線位相特性を保持し ながら, 継続時間の小さい低次系の $b_{m}(t)$ による信号処 理時間の短縮と高次系の $B_{m}(j f)$ の振幅特性 $B_{m}(f)$ の 急峻な側帯域減衰特性とを併せ備えた系を得るために, $m$ 次 B -フィル夕に同次の B -フィル夕系を並列に付加 した合成フィルタ系がある1).

Fig. 1 は 1 次 B ーフィルタによる合成フィルタ系の一 例であり上, 中および下の各段は次のようである.

上段は 1 次ラグランジュB-フィルタで, そのインパル ス応答 $b_{1}(t)$ は最大值が 1 , 継続時間が $2 T$ の三角状偶関 数対称波形である 2$)$. 中および下段では $b_{1}(t)$ の継続時間 $2 T$ を $1 / k(k=3$ および 5$)$ に圧縮し, これを $k$ 個連結し た継続時間が $2 T$ の偶関数対称波形 $\left(k\right.$ 連波) $b_{1 k}(t)$ をイ ンパルス応答とする系を形成している。これらの線形結合 $l_{1 k}(t)=b_{1}(t)+b_{1 k}(t)$ は継続時間が $2 T$ の偶数関数対称波 形であり, その周波数応答 $L_{1 k}(j f)=B_{1}(j f)+B_{1 k}(j f)$ の位相特性は直線を保持している. $b_{1 k}(t)$ の周波数応答 $B_{1 k}(j f)$ の振幅特性 $B_{1 k}(f)$ により $B_{1}(f)$ の主帯域に隣 接した側帯域スペクトル成分を相殺し, $B_{1}(f)$ と比べて 急峻な遮断特性を有する $L_{1 k}(j f)$ の振幅特性 $L_{1 k}(f)$ を 得ることができる1).

さらに, Bーフィルタに基づく直線位相巡回型ディジ タルフィルタ系があり, これは遅延・加算・係数乗算の各 要素を用いて構成できる2)。また, スイッチトキャパシタ 回路では周知のように一つの回路に遅延·加算 ·係数乗 算の機能を組み合わせることができる.

\section{3. 試作フィルタの構成および応答例}

集積化に適した直線位相アナログフィルタを実現する ために, Fig. 1 の並列合成フィルタ系と B -フィルタに よる巡回型ディジタルフィルタ系との両構成手法を併用 して, 直線位相スイッチトキャパシタフィル夕系の実回路 


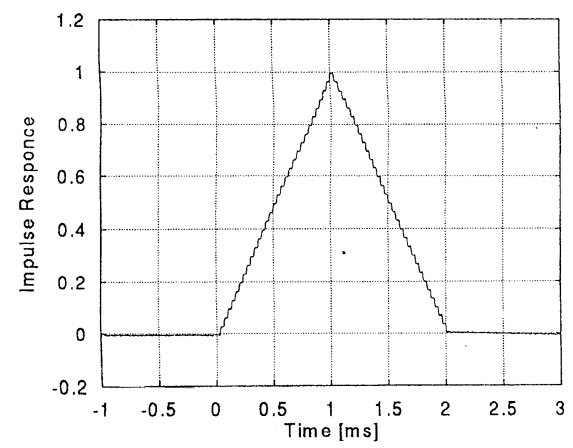

(a) First order B-filter

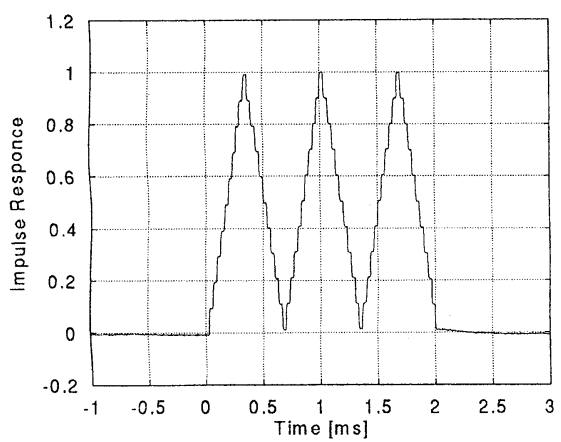

(b) Three-waves-system

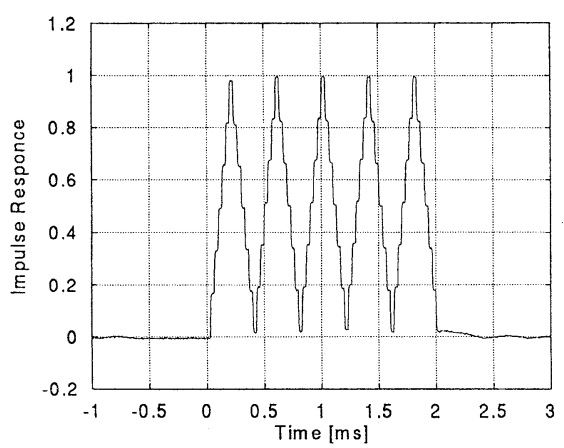

(c) Five-waves-system

Fig. 3 Impulse responses of the implemented filters

\section{4. おわりに}

キャパシタとスイッチから成るので集積化に適してい ると思われる遅延回路を新たに導入している.すなわち， フィルタにサンプル值が入力されるごとに，それを同時 に複数個のキャパシタに蓄えた後, 各キャパシタの電荷 をそれぞれ一定間隔で遅延したタイミングで取り出して いる。このような遅延回路を用いた直線位相スイッチト

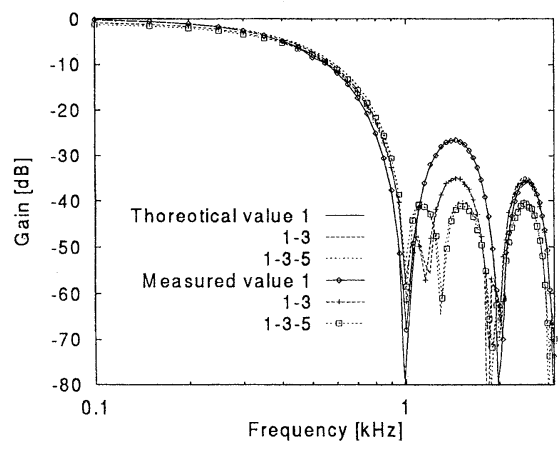

(a) Frequency spectra

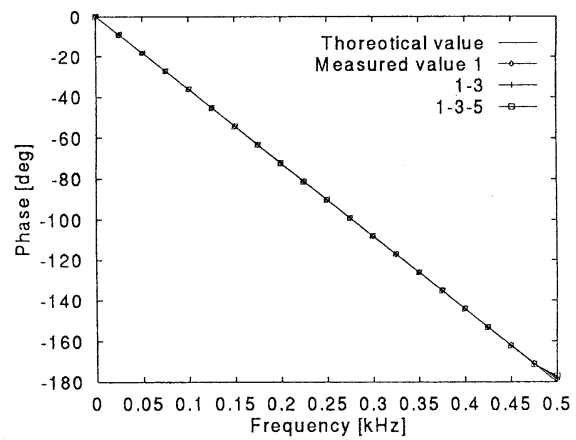

(b) Linearity of phase characteristics

Fig. 4 Frequency responses of the implemented filters

キャパシタフィルタの構成手順と試作した合成フィルタ 系の応答例を示した。応答例のそれぞれは理論値とよく 合致している.

\section{参 考文 献}

1) 金, 前田, 小野, 藤田: ラグランジュB-フイルタに基づく直 線位相フィルタの一実現法; システム制御情報学会論文誌, Vol. 7, No. 5, pp. 153-159 (1994)

2) 金, 小野寺, 浅野, 須田: 直列積分演算要素のディジタル 化に関する新手法と直線位相巡回型ディジタルフィル夕実 現への応用; 計測自動制御学会論文集, Vol. 31 , No. 8, pp. 963-972 (1995)

3) G. Di Cataldo, G. Palmisano and G. Palumbo: Gaincompensated sample-and-hold circuit for high frequency application; Electronics Letters, Vol. 29, No. 15 , pp. 1347-1348 (1993)

4) K. Nagaraj and R. E. Turner: Precision switchedcapacitor attenuator; IEEE Trans., Vol. CAS34, No. 4, pp. 446-447 (1987)

5) K. Haug, F. Maloberti and G. C. Temes: Switched capacitor integrators with low finite-gain sensitivity; Electronics Letters, Vol. 21, No. 24, pp. 1156-1157 (1985) 


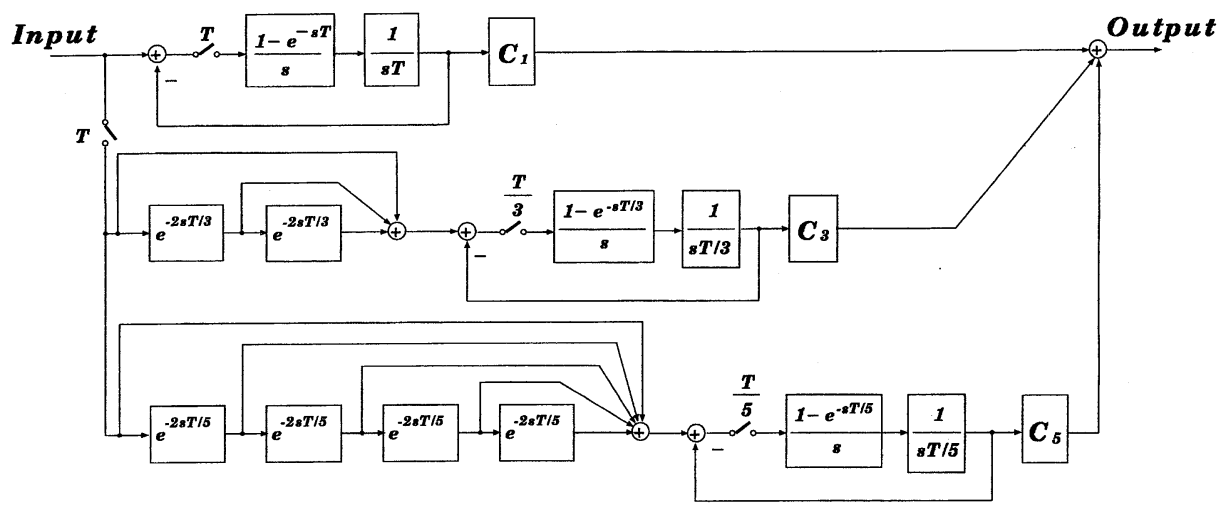

Fig. 1 Block diagram of the parallel synthesis

化を試みた. Fig. 1 内の線形加算, 零次サンプルホール ド，積分および係数の各要素の実現には在来のスイッチ トキャパシタ回路3)-5)によっている. Fig. 1 の中および 下段に在る各遅延要素 $e^{-2 s T / k}=z^{-1}$ には Fig. 2 のよ うな遅延回路を用いている。これにより，周期 $T$ の入力 離散信号系列に対し，それぞれ $2 i T / k, i=1,2, \cdots, n$, 遅延 した $n$ 個のサンプル值を得ている。なお， $k$ 連波を得る ために $2 T / k$ はスイッチトキャパシタ回路のクロック周 期 $T / n$ の整数倍である. Fig. 2(b)において, 入力信号 系列と同期した周期 $T$ のパルス列 $T_{0}$ と, これを遅延し たパルス列 $T_{1} \sim T n$ により, 同図 (a)のスイッチを開閉 する. まず入力信号系列をパルス列 $T_{0}$ によりサンプル した值をすべてのキャパシタに蓄える。そしてパルス列 $T_{1} \sim T_{n}$ により該当するスイッチを閉じると, 入力を遅 延 $z^{-1} \sim z^{-n}$ した值が得られる。このようなスイッチ動 作を組み合わせて Fig. 1 の各遅延要素を実現している. 新たに導入したこの遅延回路はキャパシタとスイッチか ら成るので集積化に適していると思われる。

計測装置 $(\mathrm{R} 9211 \mathrm{C})$ の特性を勘案し, 入力離散信号系 列の周期は $T=1[\mathrm{~ms}], T$ 区間におけるスイッチトキャ パシタ回路の積分演算回数が 30 のときの測定例が Fig. 3 および 4 である. Fig. 1 で $C_{1}=C_{3}=C_{5}=1$ としたと きインパルス入力に対する同図各段の応答が Fig. 3 であ る. Fig. 3(a) はスイッチトキャパシタ 1 次 B ーフィル夕 のインパルス応答例であり，各積分演算開始時点の值は 理論值 ${ }^{2)}$ と一致しており $T=1[\mathrm{~ms}]$ 区間における積分演 算回数は 30 であることも観測できる。また，Fig. 3(b) および (c) はそれぞれ 3 および 5 連波になっている.

Fig. 1 において $C_{1}=1$ として側帯域スペクトルの最 大值を最小にするための $C_{3}$ および $C_{5}$ の值 ${ }^{1)}$ に関する 周波数応答例が Fig. 4 である. Fig. 4(a) で, 1 次 B フィルタのみ $\left(C_{1}=1, C_{3}=C_{5}=0: 1\right.$ 系 $), 3$ 連波付加

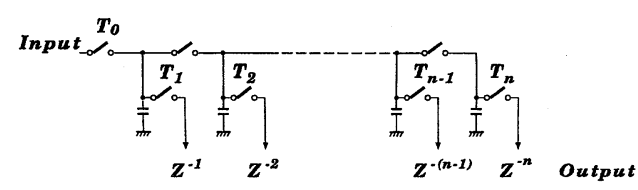

(a) Circuit

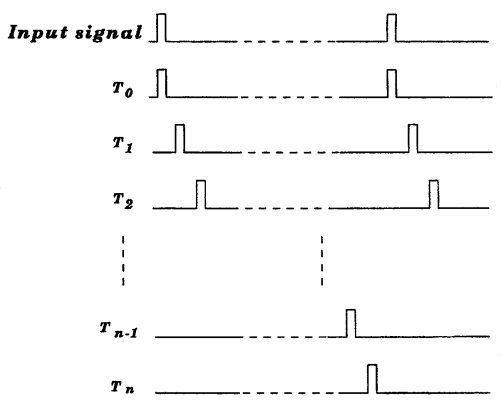

(b) Pulse train for switching operation

Fig. 2 Dalay circuit

( $C_{1}=1, C_{3}=-0.071, C_{5}=0: 1-3$ 系 $)$ および 3 と 5 の両連 波付加 ( $C_{1}=1, C_{3}=-0.089, C_{5}=-0.019: 1-3-5$ 系) のそ れぞれのゲイン $[\mathrm{dB}]$ は理論值 ${ }^{1)}$ と合致している.たとえ ば 1-3-5 系の側帯域スペクトルの最大ゲインは-39.8[dB] である。これはインパルス応答の継続時間が $2 T$ の 1 次 による合成系により, 継続時間が $3 T$ の 2 次 B ーフィル 夕と同等の值1),2)になっている. Fig. 4(b) の位相特性は 直線である。なお，参考文献 1) では， $m$ 次 $\mathrm{B}$-フィル 夕の空関数などへの応用などを考慮し, そのインパルス 応答の継続時間 $(m+1) T$ (ここでの $2 T)$ で時間軸を正 規化しているので，これに対応して Fig. 4 との間で周波 数軸の尺度も異なっている. 